\title{
EARTHQUAKES THAT HAVE INITIATED THE DEVELOPMENT OF EARTHQUAKE ENGINEERING
}

\author{
Robert Reitherman ${ }^{1}$
}

\begin{abstract}
SUMMARY
The recent $75^{\text {th }}$ anniversary of the 1931 Hawke's Bay Earthquake reminds us that a particular earthquake can have a great effect on the development of engineering methods to contend with this natural hazard. Factors other than the occurrence of a single earthquake are also present before and after such a historically important event, and there are examples of countries that began on the path toward modern earthquake engineering in the absence of any particular earthquake playing an important causal role. An earthquake that was large in seismological (e.g. magnitude) or engineering (e.g. destructiveness) measures may have had little effect on engineering tools developed to contend with the earthquake problem. The history of earthquake engineering is not merely a set of events rigidly tied to a chronology of major earthquakes. Nonetheless, some significant earthquakes have been step function events on the graph of long-term progress in earthquake engineering. Only earthquakes that bring together several prerequisites have had such historic effects, creating in a country a beachhead for earthquake engineering that persisted in the following decades. In this brief historical review, the following seminal earthquakes are discussed: 1906 Northern California, United States; 1908 Reggio-Messina, Italy; 1923 Kanto, Japan; 1931 Mach and 1935 Quetta, India-Pakistan; 1931 Hawke’s Bay, New Zealand.
\end{abstract}

\section{INTRODUCTION}

The thesis of this paper is that large, damaging earthquakes sometimes but not always have stimulated important developments in the history of earthquake engineering. These historically significant earthquakes are "beachhead earthquakes." Such events not only brought earthquake engineering to the shores of a country--they established that discipline there and kept it from being shoved back by various competing interests over the following decades. Today, when earthquake engineering is so well established in dozens of countries-seismic requirements adopted in building codes and standards, courses taught in universities, journals published and conferences held by earthquake engineering societies-it is easy to forget how difficult it was to initiate this field.

Earthquake engineering, like other new branches of knowledge, became established in a competitive environment, competing for bright minds and sustained funding as it made demands on people to adapt to change. As a new field develops, it is surrounded by Darwinian pressures inevitably exerted by competition over limited resources and the fact that people can only pay attention to a limited number of issues. As with other new disciplines, earthquake engineering had to contend with the inertia that society exerts in an unplanned but perhaps a justifiable way, because many new ideas and advocates surface every year, whereas society can only slowly be moved one way or another to accommodate those few developments that have the most motive power. To help understand the origins of our modern field of earthquake engineering, one such beachhead earthquake in each of five countries is discussed here: the United States (1906), Italy (1908), Japan (1923), India-Pakistan (1931), and New Zealand (1931). Comparisons with the 1931 Hawke’s Bay Earthquake are emphasized.

\footnotetext{
${ }^{1}$ Executive Director, Consortium of Universities for Research in Earthquake Engineering (CUREE), Richmond, California, USA
}

\section{Prerequisites for an Earthquake to Initiate Earthquake Engineering in a Country}

These beachhead earthquakes selected here for analysis have three characteristics in common. Putting the argument more strongly, these are the three prerequisites for an earthquake to be singled out as having such a historic impact on initiating earthquake engineering: (1) The earthquake was very damaging; (2) it occurred when civil engineering in general, along with seismology, had advanced to the point where earthquake engineering could extend from those fundamentals; and (3) it happened when there was at least minimal political receptivity to the idea of earthquake-resistant construction laws. The thesis presented here is not meant to be an all-inclusive explanation of how earthquake engineering originated. Thus, before proceeding with the key theme of this paper, it should be placed in context.

\begin{abstract}
Arbitrariness of Precise Historical Dividing Lines
As in other branches of history, it is somewhat arbitrary to single out one event as "the" cause of subsequent historical developments. One era fades out as another fades in, and clear dividing lines are more often used as a convenience for organising history books and courses than they are a matter of reality. The 1906 San Francisco Earthquake, for example, presented here as the most important earthquake for the initiation of earthquake engineering in the USA, is an instructive case. It occurred in a region previously affected by earthquakes and for that reason some local builders, engineers, and architects were already adding some seismic bracing to their construction. The effects of the 1906 event mingled with the influence of other events over the following years, such as the importation of advanced Japanese engineering methods in the 1920s and 1930s, and California earthquakes such as the 1925 Santa Barbara and 1933 Long Beach Earthquakes. It is
\end{abstract}


the much smaller California disaster, of 1933 that precipitated the Field Act, which applied seismic regulations to the schools run by the State of California, and the Riley Act, which applied to privately owned buildings. In turn, the existence of such building regulations and their ongoing re-evaluation and updating was a great boost to the development of engineering methods in the USA from then on. As soon as a construction standard "puts a number on" the earthquake problem-with a lateral force formula, allowable stresses and later limit state values, or safety factors and later load and resistance factorsit not only guides contemporary design. It also motivates the practising and research engineer to question those numbers, to verify them or propose better ones for future use. While recognising that 1906 was part of a seamless tableau of history, it is valid to single it out for its special historic impact, its status as a notable quantum step on the timeline, a saltation that made the earthquake engineering field in the US jump forward. In the case of the inertia of society as with the inertia of the mass of an object, the initial force that gets something moving in a particular direction, not the additional nudges that accelerate it in that direction, is the one that is most deserving of our attention.

In New Zealand, the 1855 Wairarapa Earthquake that had a magnitude over 8, as well as the earlier 1848 Marlborough Earthquake that also affected the Wellington area, had their effect on the way New Zealanders thought about earthquakes, but they are not singled out here as having the historic impact that the 1931 Hawke's Bay Earthquake had in initiating an unbroken chain of earthquake engineering developments. Beattie and Thurston [1] discuss how the superior performance of timber buildings in nineteenth century earthquakes in New Zealand, as compared to unreinforced masonry construction, had a lasting effect on construction practices. They also note that prior to the 1931 Hawke's Bay Earthquake, "Recommended Minimum Requirements for Safe and Economical Small Wooden Frame Buildings" [2] contained some seismic bracing requirements. Beattie and Thurston also point out that as a result of the 1929 Buller Earthquake in the South Island, C. E. Dixon prepared a set of construction recommendations devoted to the seismic design of wooden buildings. These earthquakes that occurred prior to 1931 had their effect, though it is still valid to single out the 1931 disaster as having unique importance.

Another proviso concerning this paper's thesis is that the unit of analysis here is the nation. This is convenient for focusing on information that can fit within the scope of a single paper, and yet one can also present the development of earthquake engineering in an international (or literally a "non-national”) context. One can trace one specific earthquake engineering development, such as the development of strong motion instrumentation, as it ricocheted from one country to another through the past century oblivious to national borders; or chronicle the careers of influential individuals; or follow the thread of one specific sub-discipline such as concrete bridge design. Historiography, the process of writing history, is approached by the author as one would draught numerous drawings of a building in order to adequately describe it: A transverse section reveals important information not seen in the longitudinal section; the plan shows still other information, as does the reflected ceiling plan, along with the elevations and various architectural and structural drawings of details. The present paper presents only one "slice" through the history of earthquake engineering. Looking at the subject from other standpoints is also necessary, but beyond the scope of this paper.

\section{Size of Earthquake, Destructiveness of Earthquake}

The earthquakes noted here are not the earthquakes largest in magnitude in recent time in these countries. Some massive seismic energy releases are "trees that fall in the forest that no one hears," being located far from any extensive development and have had little effect on earthquake engineering. To give one example, the 1855 Wairarapa Earthquake with a magnitude over 8 was an event with a bigger energy release than the magnitude 7.91931 Hawke's Bay Earthquake, but in 1855 , though the shaking, fault rupture, and tectonic elevation changes were spectacular, Wellington was a small town. Today Wellington and its adjacent cities of the Lower and Upper Hutt and Porirua have a population of half a million, and any comparable earthquake would have a damage toll of national significance. In Japan, the 1891 Nobi Earthquake was a more instructive geological event than the 1923 Kanto Earthquake. The 1891 earthquake displayed fault offsets of dramatic scale, and led the geologist Bunjiro Koto to accurately deduce that fault rupture was seismogenic - the rupture caused the earthquake shaking, not vice versa. However, the 1891 earthquake, even though it had a significant life loss, mostly affected a rural area, whereas the 1923 Kanto Earthquake struck the Tokyo-Yokohama Metropolitan region More than one earthquake in the New Madrid sequence of earthquakes in the USA in the winter of 18ll-1812 were seismologically larger than the 1906 earthquake in Northern California that devastated San Francisco, but these early earthquakes in a sparsely populated region were historically insignificant. The earthquakes discussed here were all sizable, but more importantly they struck urban regions and caused great damage and numerous casualties.

\section{Pre-Existing Engineering and Seismology Knowledge}

As noted above, earthquakes that can be singled out for their historic effect on developing earthquake engineering in a country are not necessarily the largest earthquake disasters. Large earthquakes in pre-scientific times were seeds that fell on infertile ground, from the standpoint of the development of the modern, quantitative body of knowledge and practice we call earthquake engineering. The beachhead earthquakes that put their countries on a path toward modern earthquake engineering, such as those discussed here, all occurred when civil engineers had developed their discipline with regard to non-seismic topics such as statics, dynamics, and strength of materials, to the point that they could stand on that platform and build up earthquake engineering from there. That requirement of pre-existing civil engineering knowledge has meant that an earthquake that was to boost the growth of earthquake engineering had to happen in the last half of the 1800 s or around the turn of the nineteenth-twentieth centuries or even later. The 1755 Lisbon Earthquake is often cited as an important historical event, and it is, but not for the development of engineering techniques to make buildings earthquake-resistant. There were some prescriptive, nonquantitative, non-engineered construction traditions developed after the Lisbon Earthquake and similar construction rules of thumb after the 1783 Calabria Earthquake, to imbed timber frames within masonry walls, as pointed out by Stephen Tobriner [3]. These traditions, unguided by engineering testing and numerical analysis, were on a separate, parallel path of prescriptive construction traditions with the path that led to our quantitative, experimentally-verified earthquake engineering knowledge. Prescriptive, non-calculated construction measures can still play a useful role with respect to some kinds of construction, but if the quantitative path had not been followed, our modern capability to efficiently protect society from earthquake losses would be extremely limited.

Consider the milieu in which the civil engineer worked in 1800 as compared to 1900 . In 1800 , the conceptualization of inertial forces presented in Newton's Principia, which advanced the preceding insights of Galileo on that subject, had been available for two and a half centuries. However, by itself 
$F=m a$ does not guide an engineer as to how to quantify ground shaking nor calculate the response of a structure and its resistance to earthquake forces. Lord Rayleigh's Theory of Sound, published in 1877-1878, which some would say provided the essential body of knowledge on dynamics for earthquake engineering to later develop, was a century off in the future from the earthquakes in Portugal and Italy mentioned above. And even as of the time when Rayleigh's book and other fundamentals of dynamics were being well understood, the nineteenth-century engineer still lacked any reliable notion of either the amplitude or frequency content of earthquake ground motions. In the 1870s, John Milne (18501913) and several other British professors who were brought to the University of Tokyo to develop its engineering school, were just beginning to develop measurements and inferences on how the ground and structures vibrate in an earthquake. As of 1800, one of the few seismographic instruments one can cite consisted entirely of an inked brush hanging from a cord attached to the ceiling. When an earthquake occurred, the brush made various marks tracing its pendulum motion. [4, p. 186]. But by the end of the nineteenth century, the relatively advanced Milne Seismograph existed and a rudimentary network of worldwide seismographic stations existed. Milne's colleague at the University of Tokyo, Fusakichi Omori (18681923) had by the turn of the nineteenth-twentieth century published an intensity scale [5] that began to correlate acceleration ranges with observed effects. Omori's intensity scale was partially based on experiments conducted on the world's first shake table, which he and Milne established at the University of Tokyo in 1893 . The comparison between approximately 1800 and 1900 is striking with regard to the knowledge available to the engineer about dynamics in general and as specifically applied to earthquakes: Conditions as of that turn of the century were becoming hospitable for a new branch of knowledge, later called earthquake engineering, to develop.

In the discipline of structural engineering, statics had developed during the Renaissance to the point where a horizontal force resisted by a diagonal brace could be resolved into its vertical and horizontal components, and the principle of the lever, or a moment, was known. However, none of the basic methods of truss analysis existed until after 1800, until the publication of works such as by Claude-Louis Navier (1785-1836) in 1826; Squire Whipple (1804-1888), 1847; Clerk Maxwell (1831-1879), 1864; and Wilhelm Ritter (18471906), 1862. The formula developed by Leonhard Euler (1707-1783) to analyse buckling had been in existence since 1773, but not till Thomas Tredgold (1788-1829) gave it greater engineering relevance in 1824 was a more practical design tool at hand. As the collapse of the Quebec Bridge during construction due to a buckling failure illustrated, understanding of buckling by engineers was still progressing as of 1907 . Frames with moment-resistant joints could be analysed with increasing accuracy and decreasing labour with the works of Maxwell, 1864; Otto Mohr (1835-1918), 1875; and Alberto Castigliano (1847-1884), 1873. But not till Hardy Cross produced an improved method in 1930 did frame analysis become practical for design offices to use in their daily work. Steel did not exist in 1800 for any construction purpose; in 1900 it was the material that framed dozens of large and tall buildings in many cities and had been used in the longest-span bridge in the world across the Firth of Forth. Reinforced concrete did not exist in 1800. In 1900, there were buildings and bridges being made of that material. Even if the engineers of 1800 - and there were very few who practised that profession or taught that subject as of then-were to have been handed futuristic earthquake knowledge such as response spectra and building period of vibration data, they could not have analytically followed forces through a building or bridge and calculated the resulting actions of members and connections. Ductility, so central to earthquake engineering today, was almost unknown to the engineer of 1800 , certainly with respect to being able to analyse and then design ways for the structure to mobilize inelastic capacity in an earthquake and control its response level. Along with dynamics and inelasticity, a third concept that is so characteristic of earthquake engineering today—probability—had some theoretical existence in mathematics as of 1800 . However, there were no practical design tools available to engineers then for quantifying risk of ground shaking and resulting demands, on the one hand, and the reliabilities associated with various structural capacities, on the other.

Thus, in addition to being sufficiently destructive to attract engineering attention, the historically influential earthquakes we seek to identify had to occur when science and engineering had reached a nineteenth or early twentieth century state of development. Also significant was the existence of engineering organisations by that time that developed a sense of community within the civil engineering discipline. After the pioneering era of the beginning of earthquake engineering, roughly the first half of the twentieth century, one can further generalize that the development of the earthquake engineering field required increasingly advanced developments in engineering at large, apart from earthquake engineering. This elevation of the platform from which earthquake engineering could then build further came from influences such as: research on dynamics and inelasticity in the Second World War on the effects of explosions; related research on nuclear weapons once they were invented; the finite element method development in the aeronautics industry in 1953; use of riskbased engineering analysis for the design of nuclear power plants in the 1950s and especially 1960s and 1970s; and increasing computer power that changed engineering practice in the late 1960s and 1970s and continues as a trend today.

\section{Political Receptivity}

In addition to an earthquake occurring when science and engineering were sufficiently mature, and causing a large amount of destruction, a third necessary ingredient for an earthquake to have a historic effect on launching earthquake engineering in a country has been political receptivity. While earthquake engineering theoretically could develop in the absence of any need to supply building regulations with appropriate content, in fact the existence of building laws that incorporate seismic provisions has been essential in every country for this field to rapidly grow. We take it for granted today, but imagine how earthquake research would be different-and miniscule-if there were no building regulations, no mandatory end use application. Even engineering education is guided by the provisions of the building code or building standards, and often pertinent regulations are used as important texts in the classroom. These building regulations typically begin to take on modern form in the late nineteenth century or early twentieth, another reason why earthquake engineering is largely a historical subject of the last hundred years. Tobriner [6] reviews building construction regulations from ancient to modern times, and although especially with regard to fire protection there were many pre-twentieth century precedents, structural regulations that resemble today's only appear in the latter half of the nineteenth century. While the adoption of seismic construction regulations has been both a difficult task and a notable achievement in countries around the world, in every case I am aware of it fortunately was not as difficult as it might have been: First there were laws regulating construction for gravity loads, fire, and other non-seismic concerns; then earthquake provisions were added. Also note that control of a country's seismic risk to a reasonable level involves more than engineering. Architecture, planning, seismology and geology, construction technology and practice, and the available wealth for high-quality design and 
construction are all factors, along with a society's level of respect for professional standards and the public welfare,

\section{An Example Of The Origination Of Earthquake Engineering In The Absence Of A Historically Significant Earthquake}

Before proceeding to discuss significant earthquakes that had a sudden and beneficial effect on the development of earthquake engineering in their countries, an exception to this theme should be cited. Consider the case of China, a country with a long history of devastating earthquakes, but none of which is the proximate cause of the beginnings of its earthquake engineering. Professor Liu Huixian (1914 - 1992) is by consensus in China today the founder of that countries modern era of earthquake engineering [7]. If one seminal date is to be selected in that modern period, it would be 1954, when the Institute of Engineering Mechanics was founded in Harbin. (It was initially called the Institute of Civil Engineering and Architecture). In 1956, Dr. Hu Yuxian, who the Chinese earthquake engineering community today considers the one who received the mantle of Dr. Liu, joined IEM. In 1956, as Hu points out [8], the first strategic plan was developed for earthquake engineering. One looks in vain for large, damaging earthquakes in those mid-1950s years in China. Earlier earthquakes, such as in Gansu in 1920, Xining in 1927, or 1932 again in Gansu province, were all large magnitude events - either almost 8 or over 8 - and all killed at least 70,000 people. Those disasters, however, were seeds planted prematurely, and the huge 1976 Tangshan Earthquake disaster occurred well after modern Chinese earthquake engineering was underway.

From those mid-1950s developments at IEM came the first generation of modern earthquake engineering and earthquake engineers, as well as seismic regulations, in China. This progress, rather than being instigated by a notable earthquake, was prompted by the fact that the government of China and the adjacent USSR were both communist, Soviet technicians and engineers were prevalent in China, and Soviet design provisions, which included seismic regulations, were the obvious model to adopt.

The seismic zonation maps in the Soviet building code did not include China. In what regions of China should earthquake code regulations be required at all, and how would zones be defined to trigger the relevant engineering requirements? The first approach was to map maximum historical intensities. In a country such as China where the historical record reaches back so far, analysis of that long stretch of the past had the same effect as using a very long recurrence interval for the futurevery high ground motions result. Much of the country appeared equally subject to intense earthquakes, because at some point in the past two thousand or more years there was evidence that some intense shaking had occurred. It was obviously too expensive to apply high-seismicity requirements throughout the vast country, because construction cost increases to meet the implied seismic requirements were $10 \%$ or greater. And yet it was equally obvious that portions of the country were at high risk to strong earthquakes. Thus, the change in government in China after the civil war ended in 1949, the influence of the Soviets, and the need to produce a seismic zonation map to guide engineering requirements, led to the initial development of that country's earthquake engineering. It also explains why key individuals such as Liu and $\mathrm{Hu}$, with $\mathrm{PhDs}$ in engineering rather than seismology, focused so much on seismic zonation in China's earthquake engineering program. The Chinese example proves that even in a country whose history includes major earthquake disasters, it is possible for the instigation of the development of earthquake engineering to be something else.
Given the above qualifications, the remainder of this paper discusses five countries in which a countries initiation into the field of earthquake engineering stemmed largely from a particular earthquake.

\section{THE 1906 EARTHQUAKE IN THE UNITED STATES}

The earthquake of approximately magnitude 8 that was released by the rupture of $500 \mathrm{~km}$ of the San Andreas Fault in Northern California was to be the largest earthquake in the twentieth century in the United States, outside of Alaska. Estimates of the life loss are in the range from approximately 700 , a figure often reported in the older literature such as Freeman [9, p. 8], to about 3,000, as suggested more recently by Hansen, Condon, and Fowler [10]. As in the 1923 Kanto and 1931 Hawke's Bay Earthquakes, ignitions, and rapid fire spread due to water system damage, caused great loss.

The centennial of this 1906 earthquake that was commemorated this year provides a useful vantage point from which to assess the long-term impacts it had on the development of earthquake engineering. There were some forward-looking engineering responses after the earthquake, such as in San Francisco in 1907 in the seismic design of the Globe Building, with its precocious use of reinforced brick walls made integral with a surrounding steel frame [11], but that building was exceptional. Tobriner [12] has documented that a number of architects, engineers, and builders in San Francisco, even prior to the 1906 earthquake, took earthquakes seriously and incorporated features intended to impart earthquake resistance to their structures.

However, few structural engineering or structural dynamics developments followed in the decade after the earthquake in the USA that were comparable to the advanced earthquake engineering being done at the time in Japan and Italy, and there was virtually no progress at all made with respect to adding earthquake regulations to the building code. The American approach seemed to be more qualitiative, emphasizing construction features, rather than relying on calculations of forces and stresses. Rather than adopt the seismic ratio method from abroad, for example, San Francisco and its engineers continued to rely on a surrogate wind load for seismic design purposes, and even that was set as low as 15 psf, or 720 Pascal, though some structures in San Francisco were voluntarily designed to extremely high wind/quasiseismic loads by the engineer. Another effect on engineering was the recruitment into the earthquake engineering field of individual engineers, such as Henry Dewell, Walter Huber, R. S. Chew, C. H. Snyder, H. J. Brunnier and other practising engineers in the San Francisco area; Charles Derleth, a University of California at Berkeley civil engineering professor and later dean of the school of engineering there; and Charles David Marx, the professor who established the civil engineering program at Stanford University. See Pregnoff and Rinne [13] and Tobriner [12] for details on the seismic engineering of early twentieth century San Francisco engineers.

In terms of research and education, there were some very significant long-term effects caused by the 1906 earthquake. See Reitherman [14] for further details and complete references concerning the following. The Lawson Report, [15], named after the chair of the Earthquake Investigation Commission, Andrew Cowper Lawson (1861-1952), was perhaps the most comprehensive report on an earthquake up to that time. Published within that report was the paper by Hugo Fielding Reid (1859-1944) elucidating the elastic rebound theory, which has proven central to ground motion seismic hazard studies to this day. Equally significant but less noted is the fact that the assembling of the team that compiled the 
document was in effect the recruitment mechanism by which several key individuals devoted themselves to the new field of earthquake studies. A.C. Lawson had a great effect on the initiation of earthquake studies at the University of California at Berkeley. Lawson, like many geology professors of the day, especially in the western USA, was more interested in mining than earthquakes. It was the earthquake of April 18, 1906 that changed his career course.

One of Lawson's protégés was Harry Oscar Wood (18791958), a young geology instructor at Berkeley, who was assigned by Lawson the key task of studying the intensity of shaking in San Francisco. Before the 1906 earthquake, Wood was a mineralogist; ever after he was a seismologist. Wood subsequently launched the seismographic program in Southern California of the Carnegie Institution, a foundation set up by the richest man in the world, Andrew Carnegie. At the time, the national government provided almost no funding for earthquake studies, and thus the support of the Carnegie Institution was so important. The Carnegie Institution's program begun by Wood was to be handed off in 1927 to the California Institute of Technology. This was the origin of what was to become that universities major presence in that field. By 1923, Wood had invented with astronomer John Anderson the Wood-Anderson seismograph and had begun to deploy it in a functional Southern California seismographic array. This was prior to when Caltech added a geology department in 1926, and prior to when Charles Richter (19001985) was hired by Caltech in 1927. The Wood-Anderson seismograph produced so many accurate and standardized seismograms that Richter was led to invent the magnitude scale to make sense of that data. The title of his historic paper, "An Instrumental Magnitude Scale,” [16 emphasis added] refers to the instrument Wood had the lead role in inventing. In addition to Harry Wood, John Buwalda (1886-1954) was another former Berkeley faculty member who migrated to southern California, establishing the Geology Division at Caltech, bringing with him a motivation that came from his seismic research that originated in 1906.

Meanwhile, at the other university in Northern California, Stanford University, the founder and head of the geology department, John Casper Branner (1850-1922), was also proselytized by the 1906 earthquake to enter the earthquake field with a passion. Prior to arriving at Stanford, he worked for the Pennsylvania state geological agency mapping an anthracite coal-producing region, then was state geologist of Arkansas involved in such non-seismic endeavour as mapping bauxite deposits. But absent the 1906 earthquake, what Branner would probably have concentrated on to the exclusion of seismic studies was Brazil. Branner was interested in all things Brazilian, and since Brazil is one of the least seismic regions on Earth, that did not include earthquakes. A colleague of Branner at Stanford, S. D. Townley noted [17] that in 1874, Branner studied the gold and diamond mining regions of the country on the first of his trips there, some of which lasted over a year and which totalled a decade of his life in sum. On his second trip in 1880 he studied plants suitable for making incandescent light bulb filaments, an exploration commissioned by Thomas Edison. His third research sojourn in Brazil in 1882, funded not by a geology agency but by the Division of Entomology of the US Department of Agriculture, was for the purpose of studying the cotton-worm. Alexander Agassiz next commissioned him to conduct a coastal geological survey of Brazil in 1899 with particular attention to its coral reefs. In 1907 he studied the country's diamond deposits for the Brazilian government. In 1911, the subject of his research there was the effect on ocean life of the fresh water discharged by the Amazon River. He also used his fluency in Portuguese to translate a long treatise on the inquisition in Brazil. Branner no doubt would have done fieldwork in the San Francisco Bay Area and educated his
Stanford students as to local geological features such as the expression of what he termed the Portola-Tamales Fault (later revealed to be but a small segment of the San Andreas), but even with the occurrence of the 1906 earthquake, he maintained his interest in Brazil. Without the 1906 earthquake, it is difficult to imagine him as the man who would come to dedicate so much of his career to the subject of earthquakes and wield such influence over his contemporaries in that regard.

Because of the 1906 earthquake, J.C. Branner became a leading advocate of earthquake research in California and is at the root of the family tree of earthquake research and education at Stanford University, as well as later serving as its president. Branner was also the one who encouraged fellow faculty member F. J. Rogers to build a shake table to conduct dynamic soil studies after the earthquake. In addition, Branner recruited Bailey "Earthquake” Willis (1857-1949) to take over the leadership of geology at Stanford, and also to assume Branner's role as president of the Seismological Society of America. Willis in turn was instrumental in the hiring of mechanical engineer Lydik Jacobsen (1897-1976) to the faculty. Jacobsen, who became the first president of the Earthquake Engineering Research Institute when it was constituted in 1948 and began to function in 1949, established a vibration laboratory at Stanford and was the advisor of John Blume (1909-2002). Blume was to begin his influential career in earthquake engineering in the 1930s and for many years thereafter be an important figure in the new field. Today, there are many engineers whose primary vocation is earthquake engineering, but it was a rare career path in the 1930s. In selecting a college to attend, Blume specifically chose Stanford because of its involvement in earthquake research since the 1906 earthquake. [18, p. 7-8]

The Seismological Society of America was established in San Francisco directly as a result of the 1906 earthquake, and it was operational by the end of that year. Even with the impetus of the dramatic disaster, SSA struggled financially for many years, and without the earthquake, it is unlikely such an organization would have been established until probably after

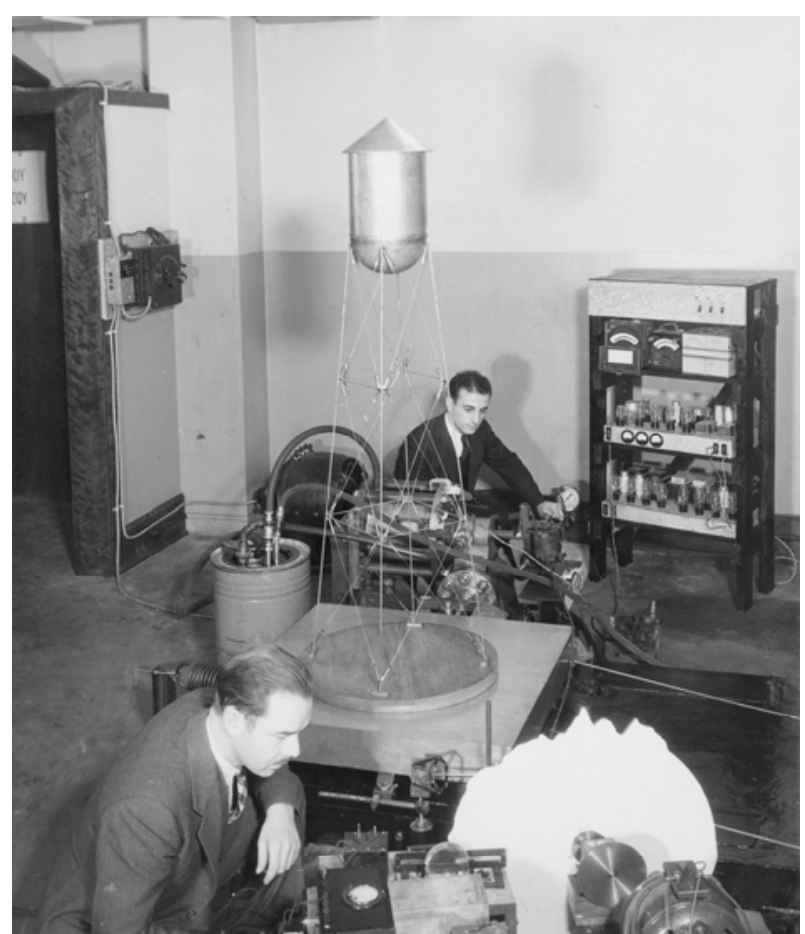

Figure 1: Arthur Ruge (foreground) conducting shake table experiments, which led to his co-invention of the electric resistance strain gauge. photo credit: MIT Museum 
the 1933 Long Beach Earthquake. A reading of the issues of the Bulletin of the Seismological Society of America in those pre-1933 years indicates what a loss to the field that delay in its establishment would have been. For example, a few years later, in 1940, in the book by S. Irwin Crookes to be discussed later, 49 BSSA articles are listed in his bibliography on earthquake engineering.

In my research, I was surprised to find out that Arthur Ruge (1905-2000), the co-inventor of the modern electric resistance strain gauge, had his "Eureka!" moment while conducting shake table experimentation in 1937 and 1938 at MIT (Figure 1). That experimentation was funded by the insurance industries concern over fire losses caused by the 1906 earthquake, a direct causal link connecting that disaster with one of the most important inventions in engineering instrumentation of the twentieth century. It is puzzling why such a momentous connection with the 1906 earthquake and earthquake engineering in general has not been previously recognized.

The now well-established series of World Conferences on Earthquake Engineering all began in 1956 with the first in that series. See Figure 2. It was no accident that 1956 was exactly 50 years after the California earthquake of 1906 . George Housner, President of EERI at the time, in his Preface in the proceedings [19] listed the first purpose of the event as "Observing by an appropriate technical meeting the fiftieth anniversary year of the destructive San Francisco Earthquake of 1906." We see an indication of the significance of the $50^{\text {th }}$

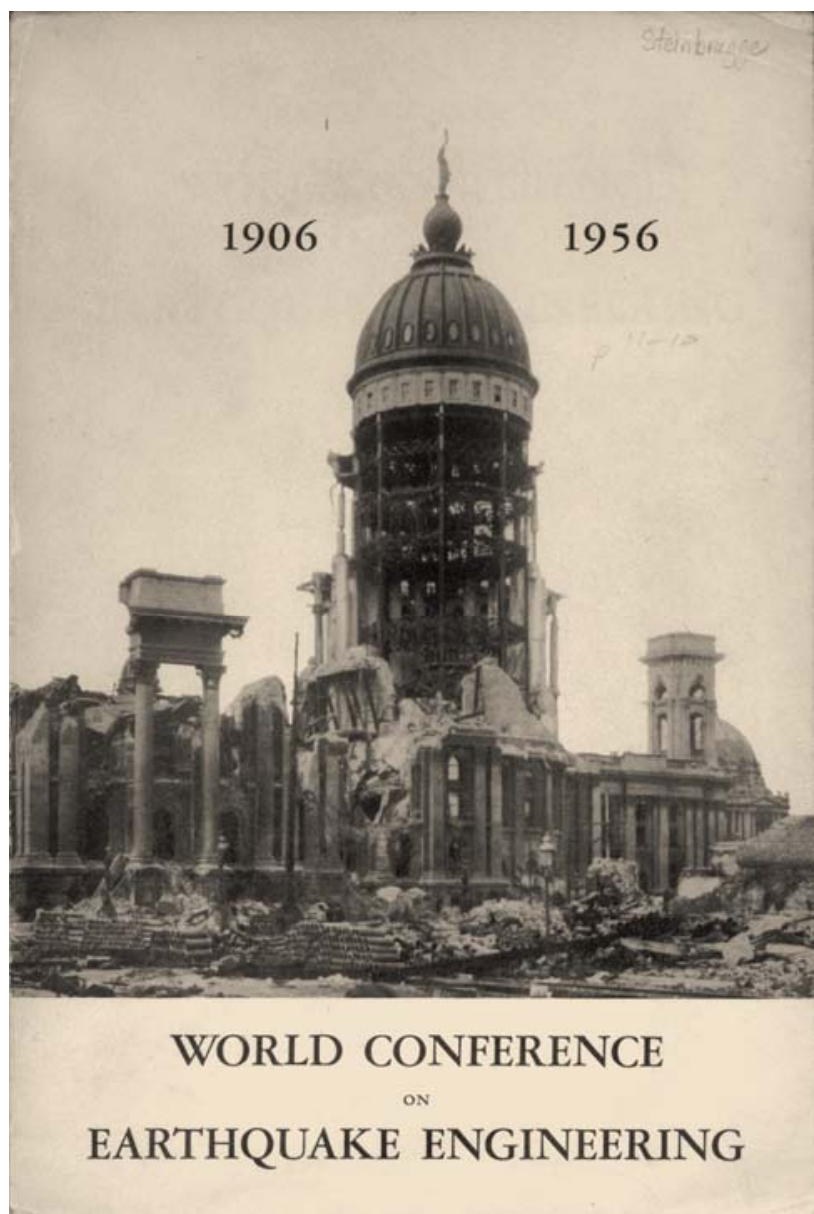

Figure 2: The first of the World Conferences on Earthquake Engineering was organised in commemoration of the 1906 Earthquake.

anniversary in helping to promote and make this first world conference a success when we look at the largest earthquake engineering conference in the USA held prior to that. Actually, it was a dual-theme conference convened in 1952 by
EERI on Earthquake and Blast Effects On Structures [20]. There was hesitancy on the part of the then-small cadre of earthquake engineers to hold an event solely devoted to earthquakes, whereas by expanding the subject to include blast effects, the potential audience was much larger. At that time, though "earthquake engineering" was in EERI's name, the term wasn't used in the proceedings of that 1952 event, because it was not widely recognized. "Engineering seismology” was much more common.

The 1906 earthquake established the credibility of the study of earthquakes in the United States, making it a worthy subject for a small but productive group of scientists and engineers to devote their careers to it in research, education, and practice. At least one such major earthquake has generally had to occur in a country before earthquake engineering has taken root there and grown. In the USA, that earthquake was the 1906 earthquake in Northern California.

\section{THE 1908 EARTHQUAKE IN REGGIO AND MESSINA, ITALY}

This earthquake located in the strait between the mainland of Italy (the city of Reggio) and Sicily (the city of Messina) caused 120,000 fatalities. See Figure 3. Earlier earthquakes in Italy had also caused massive losses, and some had inspired embryonic attempts to fashion improved construction methods to resist earthquakes, such as the 1783 Calabria Earthquake [3, 11]. But it was the 1908 earthquake that, in the opinion of an authority such as John Freeman (1855-1932), had such a historic effect on earthquake engineering. "The beginning of scientific study of the mechanics of earthquake-resisting construction followed immediately after more than 100,000 people had been killed in the Messina-Reggio earthquake of December 28, 1908. It began with the appointment of a remarkable committee, comprising nine practising engineers of large experience and five eminent college professors of engineering.” [9, p. 565] In post-1906 research and education in California, the earth scientists had a higher profile than the engineers, but in the post-1908 work in Italy, the engineers stepped forward to advance their discipline.

Luigi Sorrentino of the University of Rome La Sapienza has recently compiled and examined a number of the contemporary reports, studies, and regulations that were produced by that committee. Led by Modesto Panetti (18751957), the committee produced the seismic ratio method with rational engineering theory and also simplified it into a workable equivalent static lateral force building regulation. While Newton's quantification of inertial force, $F=m a$, had long been available, and while it was easy for engineers to compute the mass in that formula, the acceleration term in this seemingly simple equation would not easily lend itself to

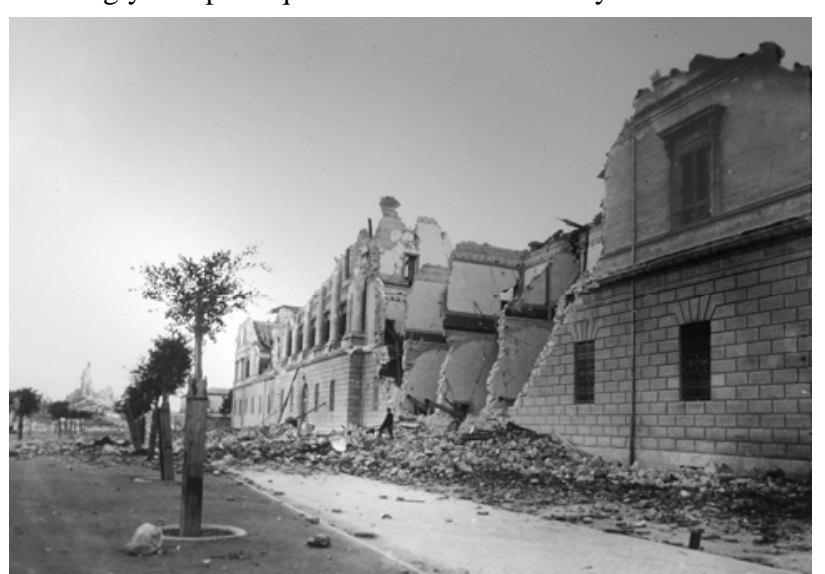

Figure 3: Destruction in the 1908 Reggioi-Messina Earthquake. 
calculations. The first strong ground motion accelerogram of modern form was only to be obtained in 1932, and useful records were only slowly to build up after that. Even with a ground motion record, because of the rapidly changing sequence of accelerations interacting with a structure's response, the seismic ratio method faced great challenges. After all, the method, which in modern form is still the most widely used means of calculating seismic design loads, in effect must reduce a complex series of varying forces down to one representative force. Reliable data on periods of vibration, damping levels, and ductility were essentially nonexistent one hundred years ago. Faced with these challenges, the Italian engineers selected a few buildings that performed well under strong shaking in the earthquake. They backcalculated an estimate for the static lateral force that these buildings were capable of resisting. They then used this to help calibrate a design lateral force ratio, the seismic acceleration divided by the gravitational acceleration, for typical kinds of construction. This leads to the familiar base shear calculation, namely the product of building weight (mass) and this seismic percentage. They also increased the design forces up the height of the building, realizing that a two- or three-story building did not displace as one rigid box, and that upper levels seemed to experience greater accelerations than lower ones. They specified a design lateral force of $1 / 12$ of the mass of the building's ground story, $1 / 8$ for the story above. We shall see that this method, called "raporto sismico" by the Italians, was independently developed by Toshikata Sano in Japan (where it was called "shindo.") An engineer who was influential though not on the committee was Arturo Danusso (1880-1968), whom Sorrentino credits with developing an early version of the response spectrum method.

This productivity in earthquake engineering that came in a brief burst of creativity, far from being an evolutionary deadend, is very recognizably part of the seismic genealogy that has resulted in the earthquake engineering we know today. According to Giuseppe Grandori [21] however, that activity was followed by decades of relative silence in the earthquake engineering field in Italy, until engineers of his generation began university research and education in the subject in the 1960s. The large earthquake in Italy that occurred relatively soon after the 1908 event, in 1915 in Avezzano, happened when the country was preoccupied with World War I. Here we have another illustration of the effect on earthquake engineering from completely different subjects in history, such as wars. There were other damaging earthquakes in Italy after the 1915 Avezzano Earthquake, but some of the key engineers involved in the 1908 earthquake studies had become absorbed in other areas, such as aircraft design or the development of a reinforced concrete construction industry for a growing infrastructure.

\section{THE 1923 KANTO EARTHQUAKE IN JAPAN}

The September 1, 1923 earthquake that struck the Kanto region, including the large cities of Yokohama and Tokyo, had a fatality toll estimated at 140,000. Although the Hawke's Bay Earthquake of 1931 was to strike a region of lesser urbanization, earthquake-caused fire in conjunction with water system disruption was a factor common to both earthquakes.

One could also cite other earthquakes in Japan that were significant in the history of earthquake engineering. The 1880 Yokohama Earthquake caused the formation of the Seismological Society of Japan, the world's first such association. The 1891 Mino-Owari Earthquake (or Nobi Earthquake) led to the formation of the Imperial Investigation Committee. (By chance, that committee's series of reports and studies, some of which consisted of more than one booklength part, reached Volume 100 on the occasion of the 1923 earthquake.) Also in 1891, Bunjiro Koto (1856-1935) accurately realized that the faulting he observed was the cause of the ground shaking, not the effect-- a key breakthrough. John Milne (1850-1913) and Fusakichi Omori (1868-1923) were influential in the development of earthquake engineering by the 1880s. Along with Milne, there were other key British faculty at the University of Tokyo (called here by its modern name, though in those years much of the work was accomplished at the branch called the Imperial College of Engineering): James Ewing (1855-1935), Cargill Gilston Knott (1856-1922), Thomas Corwin Mendenhall (1821-1924), John Perry (1850-1920), T. Gray (1850-1908), William Ayrton (1847-1908). Otani [22] notes that twenty years prior to the 1906 earthquake in California, Kiyokage Sekiya (18551896) was appointed to a full-time chair of seismology at the University of Tokyo.

These antecedent Japanese developments notwithstanding, the 1923 Kanto Earthquake can be singled out for its effect on the field of earthquake engineering. The Earthquake Research Institute was established at the University of Tokyo after the earthquake, assuming the role of the Imperial Earthquake Investigation Committee, and to this day it has been a major research and education force in the field. The earthquake caused the establishment of the first seismic regulations in a building code in the world to affect a concentration of large engineered structures - the 1924 Building Code Enforcement Regulations. [22, p. 6] Building code regulations had been passed after the 1908 earthquake in Italy and in earlier Italian earthquakes, but the 1924 legislation is historic for its application to Tokyo and other intensively developed urban areas that had large structures. The seismic ratio ("shindo") method in that code, using a $10 \%$ force level, was based on the work of Toshikata Sano of the University of Tokyo and his student, Tachu Naito (1886-1970), who became the head of structural engineering at Waseda University. Prior to that 1924 mandatory code, Naito had incorporated such thinking and carried out the necessary seismic calculations and detailing in his design of several large structures that performed well in 1923, such as the Kabuki Theater and Industrial Bank of Japan.

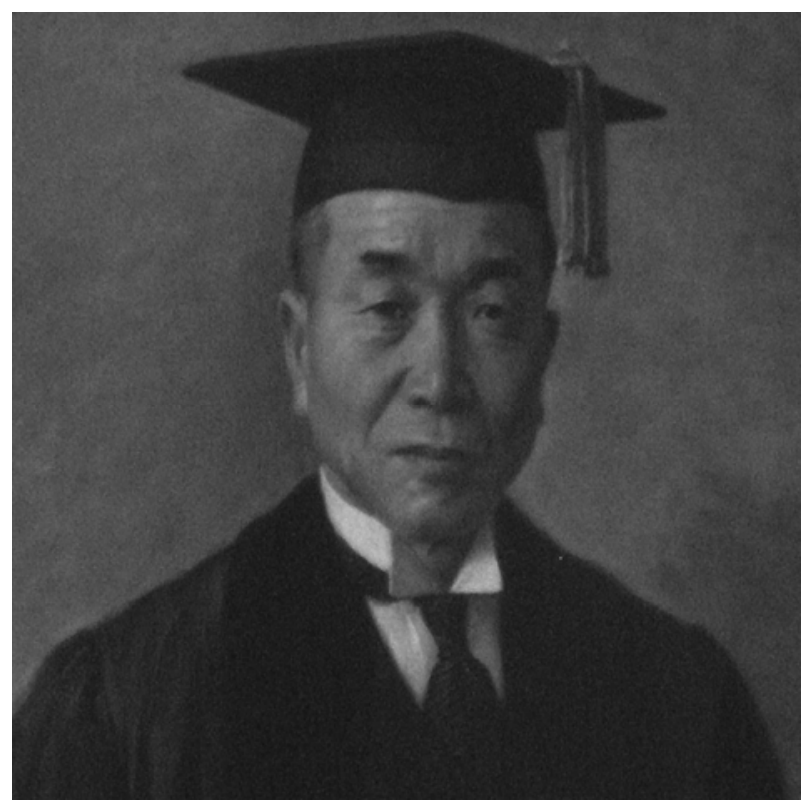

Figure 4: Portrait painting of Tachu Naito. source: Naito House, Waseda University

This was a historic first in earthquake engineering: A structural engineer employed seismic analysis computations, carefully designed the structure to resist those seismic loads, 
detailed the construction to implement new construction practices, and then saw the resulting building tested by a major earthquake. Naito's buildings performed very well in contrast to the standard non-seismic designs of an American firm doing work in Tokyo at the same time, the George Fuller Company. They also did well as compared to the significantly damaged Imperial Hotel of Frank Lloyd Wright (1867-1959). [23] Wright's admittedly brilliant architectural skills, as well as his knack for self-promotion, gave him a reputation as a heroic seismic designer in the popular press, but the engineering world was impressed by Naito. Naito's theories of seismic design conveniently had the warm-up test of the smaller Uragasuido Earthquake in 1922. Naito had recommended that the Marunouchi Building should incorporate seismic features of the steel-reinforced-concrete type, a steel frame encapsulated with reinforced concrete, but his advice was not followed and it was badly damaged in that moderate test in 1922. As if the 1923 Kanto Earthquake had been waiting impatiently to provide a confirmation that modern earthquake engineering was on the right path, the earthquake occurred only six months after Naito's treatise on earthquake engineering was published. [24] The hypothesis had been stated; the experiment was conducted; the hypothesis was verified.

Note also that Naito's sense of conservatism in the face of unknown seismological and structural engineering factors is still characteristic of good earthquake engineering today. Though one of the great figures in the development of calculation procedures in earthquake engineering, Naito stated, and perhaps overstated the underlying uncertainties for the benefit of students who might too easily assume how accurately they could calculate what the future earthquake effects on a structure would be. "In Japan, as in other seismic countries, it is required by the building code to take into account a horizontal force of at least 0.1 of the gravity weight, acting on every part of the building. But this seismic coefficient of 0.1 of gravity has no scientific basis either from past experience or from possible occurrence in the future. There is no sound basis for this factor, except that the acceleration of the Kwanto earthqake for the first strong portion as established from the seismographic records obtained at the Tokyo Imperial University was of this order." [25] Illustrating the fact that he did not trust extreme precision in seismic calculations was the fact that he used a short (14$\mathrm{cm}$ ) slide rule that his teacher Toshikata Sano had given him, rather than a longer one that would have enabled finer gradations for reading computed figures. See Figure 5. Naito believed that two decimal places of precision were adequate for seismic calculations, and that greater emphasis on precise numbers could divert the designer's attention from a more fundamental conceptualization of how the structure would actually behave. [26, p. 6]

One of the few American engineers of the time heavily involved in the young field of earthquake engineering, Harold Engle, noted that "the three buildings in Tokyo specifically designed by Dr. Naito to be earthquake-resistant actually

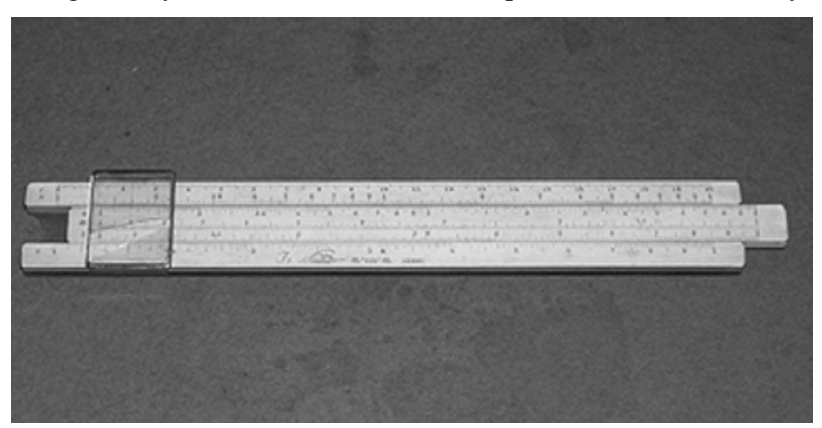

Figure 5 Tachu Naito's slide rule source: Naito House, Waseda University fulfilled their function in 1923, while many other large structures designed more along customary American lines were subject to very serious damage in many cases in the shock of 1923." [27, p. 89] Engle also stated that Naito "after 1923 made available to engineers in this country the details and design of some of those buildings that he designed before 1923 and which survived the shock so successfully.” [28, p. 39-5]

\section{THE 1931 MACH AND 1935 QUETTA EARTHQUAKES IN INDIA-PAKISTAN}

Here I give myself a waiver from my self-imposed limit of one key earthquake per country. The 1931 Mach and 1935 Quetta Earthquakes form a closely related pair that tells the story of an interesting development in the history of earthquake engineering in India. The earthquakes of August 1931 in Mach in Baluchistan, the largest of which was over magnitude 7 , occurred in what was then part of the British colony of India and is now part of Pakistan. Of interest here is the fact that the most highly engineered construction in the region, the railroad system, had significant damage, and that S. L. Kumar, a young engineer working for the railroad, was tasked with designing new earthquake-resistant dwellings for displaced railroad employees. That episode in the history of earthquake engineering as well as other details discussed here are drawn from Sudhir Jain [29]. In 1933, Kumar published his "Theory of Earthquake Resisting Design With A Note on Earthquake Resisting Construction in Baluchistan," [30] which included a seismic zonation map of India and a variation in seismic ratio from $5 \%$ to $15 \%$, depending on both the seismic zone and the importance of the structure. (Seismic ratios in different codes such as are mentioned here should not be compared without considering how live loads were included and what the allowable stresses were, which space does not allow.) Kumar was aware of the earlier work in Japan on the seismic ratio method, illustrating again how influential that work was elsewhere. Reminiscent of Naito's preference for steelreinforced-concrete was Kumar's advocacy of a steel frame embedded in concrete, or in masonry to reduce cost. Actually, his first designs incorporated iron rather than steel frames,

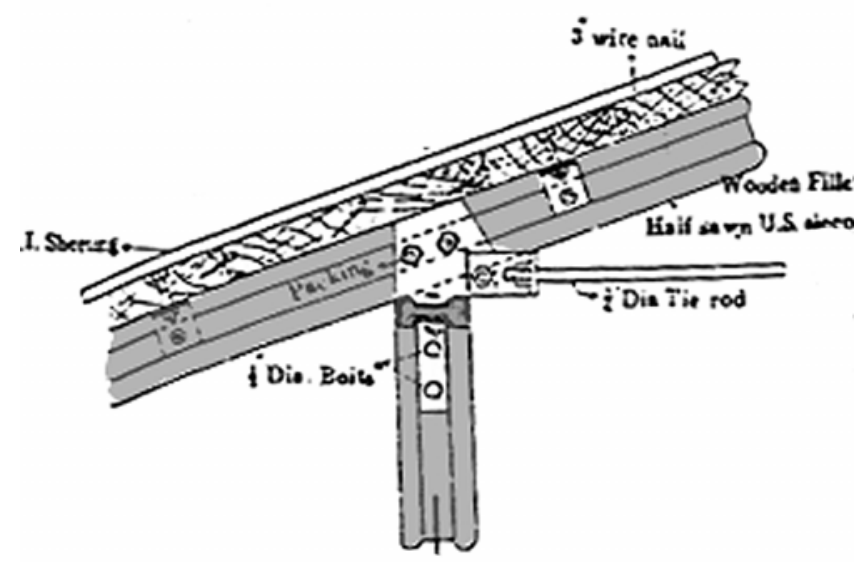

Figure 6: Section through an iron rail column/rafter/beam joint, with tie rod, and clip angle connections. Rails are shown shaded.

source: Kumar [31]

because he used the iron rails that were available within the railroad system at a time when they were being phased out and replaced with steel. Kumar devised connection details to use the rails for columns, beams, and roof truss members. The metal framing may have functioned more as containment members for the unreinforced masonry infill, instead of the walls and frames acting as what an earthquake engineer today 
would call a dual system of shear walls and moment-resisting frames. In addition, the metal members supported vertical loads and absorbed any thrust on walls induced by roof loads. Two other aspects of this account of early Indian earthquake engineering are similar to the story of Tachu Naito and the 1923 Kanto Earthquake: Not only did Kumar design buildings with a particular seismic design method and lay out the theory of his approach and publish it prior to the earthquake--in addition Kumar's buildings were soon tested by a major earthquake. In the magnitude 8 Quetta Earthquake on May 30, 1935, a disaster that killed 20,000, Kumar's buildings did very well, while the others in the vicinity were badly damaged or collapsed. As Jain [29. 320] notes, "For the first time in India, the effectiveness of earthquake-resistant construction was tested during a severe earthquake.” In India, the 1935 Quetta Earthquake marks the start of the first seismic regulations in the building code, an effect comparable to that of the Hawke's Bay Earthquake on construction standards in New Zealand.

\section{THE 1931 HAWKE'S BAY EARTHQUAKE IN NEW ZEALAND}

Pre-1931 earthquakes, such as 1848 and 1855 near Wellington and 1929 in Buller, were mentioned earlier. Another important pre-1931 development that should be cited is the 1926 book by Charles Reginald Ford (1880-1972) on seismic design [32]. Park has cited the fact that this seems to be the first book-length treatment in English on earthquake engineering. [33, p. 9] As a young man, Ford served for several years aboard the Antarctic exploration vessel Discovery under Robert F. Scott at the turn of the nineteenthtwentieth century. He later became an architect, and his practice with W. H. Gummer was one of New Zealand's most successful in the 1920s and 1930s. He was already a member of the Concrete Institute of London before he wrote his 1926 book, and a visit to California in 1922 may have introduced him to some early seismic influences. [34] Ford's work did an admirable job of summarizing current thinking in Japan, the US, and Italy on the subject of earthquake-resistant design, as well as going on to propose effective solutions for New Zealand construction types. His early work emphasizes construction quality and rules of thumb for different materials, but it also ventures into calculations of seismic stability and stresses on columns, and ventures the opinion that buildings in New Zealand should be designed for a lateral force coefficient of $10 \%$. Along with advocating incorporation of seismic regulations in local government by-laws and the convening of a joint committee of New Zealand architects and engineers to draft such a model standard, Ford was in support of including earthquake engineering into the architecture and engineering curriculum at the University of Auckland. With our 80 years of hindsight, Ford's work is an impressive accomplishment. In the context of this paper, it is also significant that it is a relatively isolated case. Prior to the 1931 Hawke's Bay Earthquake, such a broad search for the world's seismic knowhow and thoughts on how to apply those lessons to New Zealand was an anomaly; after the Hawke's Bay Earthquake, New Zealand had (at least in some municipalities and in the work of national agencies) seismic regulations. The Hawke's Bay Earthquake met the three basic criteria for establishing an earthquake engineering beachhead: (1) great destructiveness; (2) existing engineering knowledge (e.g., analysis methods for reinforced concrete walls and moment-resisting steel frames existed and were taught in New Zealand); (3) there was political receptivity to legislating seismic regulations.

From an earth sciences perspective, the large magnitude, 7.9, of the February 3, 1931 Hawke's Bay Earthquake immediately made it noteworthy. For example, in the classic textbook by John Milne, as updated by Lee [35], the seismogram recorded at the Kew Observatory in London of this New Zealand earthquake is singled out for its instructiveness with respect to reflection and refraction of waves through the earth. The aftershocks were also well studied. Surface faulting was noted. What are usually called ground failures occurred in abundance. Liquefaction and seismic compaction caused water pipeline damage, contributing to the great fire loss in Napier and Hastings. Landslides cut off roads. In addition, the term "ground failure" seems inadequate to describe the effect of the earthquake on the scale of the overall landscape of the greater Napier region: $1500 \mathrm{sq} \mathrm{km}$ of what had been marshes or part of the sea suddenly became dry land due to uplift. Docks and boats were left high and dry. When one flies to Napier today, the airplane lands where fish previously swam. All in all, the 1931 earthquake provided a rather comprehensive catalogue of earthquake phenomena.

It is primarily the effects of the earthquake on engineering and construction that are of most relevance here, though earthquake engineering has progressed hand-in-hand with its sister discipline of seismology. (To be more precise, we should refer to the sister discipline of strong motion seismology — earthquakes as they affect Earth's surface—as distinct from the use of seismology to study Earth's interior). On the city planning scale, Napier today has a low-rise, Art Deco characteristic that makes it unique in New Zealand. After the damage to Lisbon from ground shaking, fire, and tsunami in the 1755 earthquake, the Baixa central business district was rebuilt along then-modern lines, with a grid street

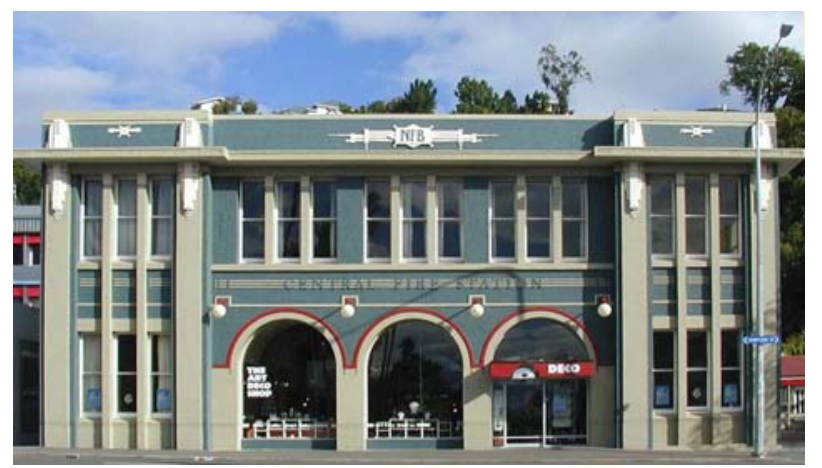

Figure 7: The current Art Deco Trust Building in Napier, New Zealand, formerly a fire station. The front portion is an exact replica, in reinforced concrete, of the unreinforced brickwork that partially collapsed in the 1931 Hawke's Bay Earthquake. The rear portion of the structure, made of reinforced concrete, survived.

\section{photo credit: Art Deco Trust}

system. Another example of city-scale impact on a city's post-earthquake construction is the re-building of Noto in Sicily in the Baroque style of the day after that medieval town was so badly damaged in the 1693 Sicilian Earthquake. [36]. In Napier, the architectural impact of the earthquake and the reconstruction is well chronicled by McGregor [37, 38, 39]. Earthquake engineering considerations as well as the architectural style of the day were significant in determining how the city would re-build. In Napier, "the masonry buildings were severely damaged in almost all cases, although the new concrete ones generally survived.” [38, p. 19] Steel was a relatively expensive and hard to obtain material, especially in those days of the Depression. At that time, when George William Forbes was Premier, the country like the rest of the developed world had already been in a depression since 1929, but it hit New Zealand especially hard. For example, the national debt was one of the largest in the world on a per capita basis, and paying the interest on that debt accounted for $40 \%$ of the government's expenditures. [40, p. 264] For 
reasons of both economy and the good performance displayed in the earthquake, reinforced concrete was thus the logical choice for the new Napier. If forced to name only one of the primary structural materials that New Zealand earthquake engineering has concentrated on, it would probably be reinforced concrete and its relatives, precast and prestressed concrete. Dowrick [41] notes the generally good performance of reinforced concrete buildings in Napier in the 1931 earthquake, even though they had not yet benefited from seismic design, as compared to the great damage to unreinforced masonry buildings: Unreinforced masonry damage caused 240 of 254 fatalities.

The development of earthquake engineering research on concrete buildings began in the 1960s by the generation of people such as Robert Park (1933-2004) and Thomas Paulay who had no direct connection to the Hawke's Bay Earthquake. However, that best known of New Zealand earthquakes had some effect in boosting the trend toward reinforced concrete construction, just as the 1923 Kanto Earthquake did in Japan. Also noted by engineers of the time was the benefit of including a complete structural frame in a building, even if load-bearing walls were also present.

The development of earthquake engineering is not merely a chronology of the evolution of a country's building regulations, but it is almost always true that in the absence of such regulations, earthquake engineering is a subject of little interest. As Murphy noted in 1956 in the report on New Zealand at the first of the world conferences, the Hawke's Bay Earthquake led to the inclusion of seismic regulations in the New Zealand Standard Code of Building By-Laws [42, p. 211]. Megget [43] notes that from the mid-1930s until a decade after the time when Murphy wrote, the regulations that were produced because of the Hawke's Bay Earthquake were little changed. The original regulations were of the seismic ratio type used in Japan, without explicit factors accounting for dynamic effects, but once an engineering standard was in place, there was a framework that could be improved upon, which began to happen rapidly in the mid 1960s.

The head of the special national committee set up by the government to study the 1931 earthquake, the Building Regulations Committee [44] was J. E. L. Cull, who was the chairman of the Civil Engineering Department at Canterbury College (later to be the University of Canterbury). The Committee's regulations made their way into law in 1935, as explained by Megget [43], and more than any other document the Committee's report is the parent of all subsequent New Zealand seismic regulations. It was also an important force at that time for instituting nationwide standardized regulations that applied to all aspects of building construction. While the Committee noted the problem of the danger posed by existing buildings, it was, as one might expect for that time, an issue to be dealt with later, after building regulations for new buildings had become well established. Their call for "a systematic survey of all doubtful buildings" [44, p.6] is currently being realised with the rating system developed by a study group of the New Zealand Society for Earthquake Engineering and recommended by the Department of Building and Housing for use in meeting Building Act 2004 requirements with regard to existing buildings [45].

S. Irwin Crookes, a lecturer at the School of Architecture of the University of Auckland, wrote an influential text in 1940 [46] that was in effect an updating and extension of Ford's 1926 book. The work by Crookes seems to have been influenced more by contemporary engineering thought in California and Japan than by the 1931 Hawke's Bay Earthquake. In particular, his book came at a time when some initial ground motion records were available (though his book was published just before the $1940 \mathrm{El}$ Centro strong motion record was obtained). Overall, it is much more quantitative than Ford's. Because the California regulations instituted after the 1933 Long Beach Earthquake were well-codified and had been used on thousands of school buildings by 1940, Crookes reprinted them in full in an appendix to his work. Park has noted [33, p. 9-10] that the 1931 Hawke's Bay Earthquake jolted New Zealand into the search for architectural and engineering guidance from countries with new seismic design philosophies, rather than continued reliance on non-seismic traditions from Europe, such as use of unreinforced masonry.

The book by Crookes in 1940, in comparison with the one by Ford in 1926, reflects the increasing awareness of dynamic effects on structures in earthquakes. In a sense, the initial focus of engineers was on strength, whereas the great significance of stiffness in seismic design was appreciated later. Even today, one can generalize that for gravity loads, engineers focus mainly on strength, with floor deflections checked only as a minor part of the design effort. In seismic design, by contrast, stiffness (as it relates to periods of vibration, distribution of forces, drift limits or target displacements) is central. Engineers of the time could understand the fundamentals of dynamic response but did not yet have a full tool kit with which to design structures to put those principles to practical use. Crookes notes that "The engineer who is asked to design an earthquake-resistant building has, therefore, an entirely different feeling about it from that which he would have if asked to design the same building along normal lines.” [46, p. 2] A feeling of concern, a belief that the earthquake hazard is imminent and therefore adequate engineering countermeasures are essential, is a personal characteristic that has been shared by earthquake engineers around the world who helped develop the field in its early years. If it is not a quality shared by the generations that have entered the field more recently, in the author's opinion it is regretable. For the earthquake engineer to take the task of seismic design seriously, it is necessary to believe that the construction being designed will actually go through an earthquake. That sounds simplistic, and it may seem mystical to say that seismic design is partly a matter of "belief," but consider why the pioneering earthquake engineers of the twentieth century took this subject so seriously. They had the personal belief that if they didn't adequately design their buildings and bridges, the construction could fail in an earthquake, and they had seen what that destruction looked like. It is difficult to have that belief if your country has not had a large, damaging earthquake. Thus, aside from the learning of specific engineering lessons that follows such earthquakes, as described earlier, these events have each made the important point that such natural hazards have indeed materialized, and will materialize in the future, and that it is the engineer's duty in that country to adequately design for them. In New Zealand, it was the 1931 Hawke's Bay Earthquake that was most responsible for instilling that concern among the countries engineers.

As time went on, the seismic ratio method, developed originally in Italy and Japan as discussed above, was modified in the New Zealand building by-laws to resemble contemporary American practice, such as the "Lateral Forces of Earthquake and Wind" produced in 1952 by a joint committee of the American Society of Civil Engineers and the Structural Engineers Association of Northern California, cited as being influential by Murphy [42]. In the 1960s, the era begins when New Zealand earthquake engineering rapidly progressed and set its own course and soon was to become a net exporter rather than importer in this field. A lengthy but succinct quotation in that time (1969) from Robin Shepherd [47, p. 200-201] summarizes the eras of New Zealand earthquake engineering, with the Hawke's Bay Earthquake being at the pivot point of that line:

"Appreciation of some basic aspects of earthquake engineering was probably stimulated by the 1848 
and 1855 Wellington earthquakes which caused major damage to one of the first organised European settlements, shortly after its inception. Certainly the satisfactory performance of timber framed structures prompted the general adoption of this constructional form at the expense of the traditional masonry bearing-wall type of building, which suffered severely in these disturbances.

"However more than seventy years passed before another New Zealand earthquake caused loss of life and in that time many of the lessons learnt by the early settlers had been forgotten. During this period the seismic disturbances which occurred were not sufficiently close to populated areas to cause major structural damage, but the 1929 Murchison and the 1931 Napier shocks, with their consequent toll of lives and property, refocussed attention on the seismic risk problem.

"Following the Napier earthquake much attention was devoted to earthquake engineering study in New Zealand. The British Building Research Station was commissioned to undertake a literature survey and various groups within the country including the Department of Scientific and Industrial Research, the Institute of Architects, the Public Works Department and the Society of Civil Engineers contributed towards the specification of adequate and acceptable seismic design criteria. As a result in 1935 a New Zealand Standard Model Building Bylaw, incoporating a rational seismic design procedure, was published.

"In the following thirty years only minor modifications to this code reflected the slow progress made in accumulating the basic information necessary to enable the obvious inadequacies of the code to be improved. Nevertheless in 1965 the current building code [New Zealand Standard Model Building Bylaw of 1965] was published and for the first time the dynamic nature of the problem was recognised in the code provisions. 1965 was significant also for the holding, in Auckland and Wellington, of the Third World Earthquake Engineering Conference which enormously stimulated interest in the subject within New Zealand....It was in this environment that the New Zealand Society for Earthquake Engineering was conceived [in 1968].”

Innovative seismic design thinking by practitioners such as J.P. Hollings and Lyall Holmes, encouragement of improvements to building standards by government officials such as Otto Glogau, investigations by government agency scientists and engineers such as Ivan Skinner, research by university professors such as Bob Park, Tom Paulay, and Nigel Priestley, and activities of the NZSEE are all part of the era that began in the mid 1960s and extends to today. The subject of the present era lies beyond the scope of this paper, except to point out that the 1931 Hawke's Bay Earthquake was more influential than any other in preparing the way for the current era of progress in earthquake engineering in New Zealand.

\section{CONCLUSIONS}

The thesis of this paper is that large or disastrous earthquakes sometimes but not always have stimulated important developments in the history of earthquake engineering. A corollary is that leading nations in the field of earthquake engineering typically experienced at least one earthquake of disastrous impact within relatively modern times before a high priority was placed on earthquake engineering. The three prerequisites identified for an earthquake to be historically significant in initiating the development of earthquake engineering in a country are: (1) the earthquake was sufficiently destructive; (2) it occurred at a time when civil engineering had developed to the point where seismic design could be extended from that pre-existing foundation; and (3) there was political receptivity to dealing with the earthquake hazard, especially with regard to adopting construction regulations. The earthquakes discussed here, culminating with the 1931 Hawke's Bay Earthquake, whose 75th anniversary has been commemorated this year, all stop short of the current era of earthquake engineering. The scope here is focused on the origins of our modern era of earthquake engineering rather than its present state.

Predicting what effect a future significant earthquake in New Zealand might have on earthquake engineering is even further beyond the scope of this paper, as well as the capabilities of the author. However, I will speculate that some or even all of the following ten characteristics of New Zealand earthquake engineering that have been evident in the past [33, p. 144-151] will exert their influence when that future major earthquake occurs.

1. Framing of research agendas around the needs of engineering practice;

2. Efficient communication of developments in New Zealand to other countries;

3. Placing at least as much importance on experimental discovery and verification concerning the "capacity side of the equation" as on software development and analysis on the "demand side of the equation";

4. Lack of liability and litigation barriers to implementation of needed innovations;

5. Absence of a heavy bureaucratic burden imposed by government agencies and regulations;

6. Recognition of seismic risk as a nationwide problem;

7. Capitalizing on the small size of the nation to facilitate communication and dissemination of new ideas;

8. Close collaboration among universities, practising engineers, the construction industry, and government;

9. Evolution along its own earthquake engineering path because of geographic remoteness;

10. Influences on earthquake engineering exerted through the traits of the New Zealand people in general, especially the pioneering tradition of selfreliance.

\section{ACKNOWLEDGMENTS}

The Earthquake Engineering Research Institute (EERI) and Federal Emergency Management Agency (FEMA) award of the 2005 NEHRP Professional Fellowship enabled me to collect information on "The Development of Earthquake Engineering From An International Perspective.” Professor Vitelmo Bertero is my faculty advisor for that research. In the USA, serving as co-editor with William Holmes of the EERI theme issue of Earthquake Spectra on the centennial of the 1906 earthquake in California helped me concentrate on compiling information on that earthquake, some of which is presented here, and I learned much from the other authors in that issue. Visits and correspondence with peoople in the following countries informed my research on the history of 
earthquake engineering: Luigi Sorrentino, Camillo Nuti, Vicenzo Petrini, Giorgio Franchioni, and Giuseppe Grandori in Italy; Sudhir Jain in India; Tetsuo Kubo, Hitoshi Shiohara, Keiji Doi, Toshibumi Fukuta, Shunsuke Otani, and Makoto Yamada in Japan; Hu Yuxian, Zengping Wen, Li-Li Xie, Feng Fan, Xiaxin Tau, Li Shanyou, Junwu Dai, and Zifa Wang in China. With regard to New Zealand, having the opportunity to interview Tom Paulay and the late Bob Park for their oral history book jointly published by the Earthquake Engineering Research Institute and the New Zealand Society for Earthquake Engineering in 2006 provided valuable background information and was a very rewarding personal experience. Les Megget of the University of Auckland kindly reviewed a draft of this paper. Bruce Deam of the University of Canterbury provided access to the 1926 book on earthquake-resistant design by C. Reginald Ford. Noel Evans of Opus provided me with a copy of the Report of the Building Regulations Report of 1931 on the Hawke's Bay Earthquake. Robert McGregor of the Art Deco Trust in Napier kindly met with me and explained the historic background to post-Hawke's Bay Earthquake reconstruction there. Some of the material in this paper has been derived from my shorter paper "Effects of Significant Earthquakes On The Development of Earthquake Engineering” for the 2006 annual conference of the NZSEE, (Proceedings of the New Zealand Society for Earthquake Engineering 2006 Conference: Remembering Napier, 1931).

\section{REFERENCES}

1. Beattie, G. J. and S. J. Thurston (2006) "Changes to the seismic design of houses in New Zealand”. Proceedings of the 2006 New Zealand Society for Earthquake Engineering Conference, Napier, March 10-12, 2006.

2. Government Print (1924) Building Conference Relating to the Use of Timber in Building Construction, New Zealand State Forest Service Circular No. 14.

3. Tobriner, Stephen (1983) "La casa baraccata: earthquake-resistant construction in 18th century Calabria." Journal of the Society of Architectural Historians, $\mathbf{4 0}$ (2).

4. Dewey, James and Perry Byerly (1969) "The early history of seismometry (to 1900)," Bulletin of the Seismological Society of America, 59, (1), February 1969. 183-287.

5. Omori, Fusakichi (1900) "Seismic experiments on the fracturing and overturning of columns". Report by the Earthquake Investigation Committee. 4. 69-141.

6. Tobrinier, Stephen (1984) "The history of building codes to the 1920s". Proceedings of the Structural Engineers Association of California Conference, 1984.

7. Xie, Lili (2004) "The father of Chinese earthquake engineering - Professor Liu Huixian”. Proceedings of the International Conference on Advances and New Challenges in Earthquake EngineeringResearch In Honor Of The Late Professor Liu Huixian, August 1520, 2002, Harbin and Hong Kong. Institute of Engineering Mechanics.

8. Hu, Yuxian (2002) "Earthquake engineering in China," Earthquake Engineering and Engineerinbg Vibration. 1 (1), June 2002.
9. Freeman, John Ripley (1932) Earthquake Damage and Earthquake Insurance. New York: McGraw-Hill.

10. Hansen, Gladys, Emmet Condon, David Fowler (1989) Denial of Disaster: The Untold Story and Photographs of the San Francisco Earthquake and Fire of 1906. San Francisco: Cameron and Co.

11. Tobriner, Stephen (1984) "A history of reinforced masonry construction designed to resist earthquakes: 1755-1907,” Earthquake Spectra. 1 (1), November 1984.

12. Tobriner, Stephen (2006) Bracing For Disaster: Earthquake-Resistant Architecture and Engineering in San Francisco, 1838-1933. Berkeley, California: Heyday Books.

13. Pregnoff, Michael, and John Rinne (1996) Michael V. Pregnoff and John E. Rinne: The Earthquake Engineering Research Institute Oral History Series. Stanley Scott interviewer. Oakland: Earthquake Engineering Research Institute.

14. Reitherman, Robert (2006) "The effects of the 1906 earthquake in California on research and education," Earthquake Spectra, 22, T1, April, 2006. 207-236.

15. Lawson, A.C., et al. (1908) The California earthquake of April 18, 1906. Washington, DC: Carnegie Institution; reprinted 1969.

16. Richter, Charles (1935) “An Instrumental Magnitude Scale,” Bulletin of the Seismological Society of America, 25, (1), January 1935. 1-32.

17. Townley, Sidney D. (1922) "John Casper Branner." Bulletin of the Seismological Society of America, 12, (1), March, 1922.

18. Blume, John A. (1994) John A. Blume: The Earthquake Engineering Research Institute Oral History Series. Stanley Scott interviewer. Oakland: Earthquake Engineering Research Institute.

19. Housner, George (1956) "Preface," Proceedings of the World Conference on Earthquake Engineering, Berkeley, California, June 1956. Oakland: EERI.

20. Duke, C. Martin and Morris Feigen, editors (1952) Earthquake and Blast Effects on Structures. Oakland: Earthquake Engineering Research Institute.

21. Grandori, Giuseppe (2005) personal communication.

22. Otani, Shunsuke, (2004) "Earthquake resistant design of reinforced concrete buildings: past and future,” Journal of Advanced Concrete Technology, 2, (1), February 2004, Japan Concrete Society.

23. Reitherman, Robert (1980) "Frank Lloyd Wright's Imperial Hotel: A Seismic Re-evaluation”. Proceedings Of The Seventh World Conference On Earthquake Engineering, Istanbul, 1980.

24. Naito, Tachu (1923) "Theory of earthquake-resistant construction," Journal of the Architectural Institute of Japan, published serially, 1922-1923, the last instalment in March of 1933. 
25. Naito, Tachu (1939) "Notes on earthquake resistant construction.” Spring, 1939 lecture series, University of Santo Tomas, Philippines.

26. Tachu Naito Publishing Committee (1986) The Centennial Celebration of Tachu Naito. Centennial Celebration of Tachu Naito Publishing Committee, Waseda University.

27. Engle, H. M. (1929 "The earthquake resistance of buildings from the underwriters' point of view,” Bulletin of the Seismological Society of America, 19, (2), June, 1929.

28. Engle, H.M. (1956) "Synopsis of panel discussions," Proceedings of the World Conference on Earthquake Engineering, Berkeley, California, June 1956. Oakland: Earthquake Engineering Research Institute

29. Jain, Sudhir (2002) "Codes, licensing, and education," in Bhuj, India Earthquake of January 26, 2001 Reconnaissance Report, supplement to 18, Earthquake Spectra, 2002.

30. Kumar, S. L. (1933) "Theory of earthquake resisting design with a note on earthquake resisting construction in Baluchistan," Paper No. 165, Punjab Enginering Congress.

31. Kumar, S. L., 1932 "Theory of Earthquake Resisting Design With A Note on Earthquake Resisting Construction in Baluchistan," Proceedings of the ASCE, May 1932.

32. Ford, C. Reginald (1926) Earthquakes and Building Construction. Auckland: Whitcombe \& Tombs, Ltd.

33. Park, Robert and Paulay, Thomas (2006) Robert Park and Thomas Paulay: The Earthquake Engineering Research Institute Oral History Series. Robert Reitherman, interviewer. Oakland: Earthquake Engineering Research Institute

34. New Zealand Historical Association (2006) "Charles Reginald Ford," Dictionary of New Zealand Biography. On-line publication at http://www.dnzb.govt.nz/dnzb.

35. Milne, John and A. W. Lee (1939) Earthquakes And Other Earth Movements. London: Kegan Paul, Trench, Trubner, \& Co.

36. Tobriner, Stephen (1983) Genesis of Noto: An Eighteenth Century Sicilian City. Berkeley: University of California Press.

37. McGregor, Robert (1999) The New Napier: The Art Deco City in the 1930s. Napier: Art Deco Trust.

38. McGregor, Robert (2002) The Hawke's Bay Earthquake: New Zealand's Greatest Natural Disaster. Napier: Art Deco Trust, second edition.

39. McGregor, Robert, (2003) The Art Deco City: Napier, New Zealand. Napier: Art Deco Trust, fourth edition.

40. Sinclair, Keith (2000) A History of New Zealand. Auckland: Penguin.
41. Dowrick, D. J. (2006) "Lessons from the performance of buildings in the $M_{w} 7.8$ Hawke's Bay Earthquake of 1931," Proceedings of the 2006 New Zealand Society for Earthquake Engineering Conference, Napier, March 1012, 2006.

42. Murphy, Vernon A. (1956) "Earthquake engineering developments in New Zealand, 1945-1955," Proceedings of the World Conference on Earthquake Engineering, Berkeley, California, June 1956. Oakland: Earthquake Engineering Research Institute.

43. Megget, L. M. (2006) "From brittle to ductile: 75 years of seismic design in New Zealand.” Proceedings of the 2006 New Zealand Society for Earthquake Engineering Conference, Napier, March 10-12, 2006.

44. Buildings Regulations Committee (1931) "Report of the Building Regulations Committee,” J.E. L. Cull, Chairman.

45. New Zealand Society for Earathquake Engineering (2006) Assessment and Improvement of the Structural Performance of Buildings in Earthquakes: Recommendations of a NZSEE Study Group on Earthquake Risk Buildings, June 2006.

46. Crookes, S. Irwin (1940) Structural design of earthquake-resistant buildings. Auckland: Leightons Ltd.

47. Shepherd, Robin (1969) "Leading article: New Zealand earthquake engineering education," Bulletin of the New Zealand Society for Earthquake Engineering, 2, (3), September, 1969. 